\title{
Bilingual Education at the post-secondary level; A Case Study
}

\author{
VIVIANE EDWARDS*
}

\begin{abstract}
In 1983, the University of New Brunswick adopted a French Language Policy which called for courses to be offered in French in a number of disciplines, including Economics, History and Political Science. This article discusses the events which led to the adoption of the Policy and the difficulties as well as successes which the Policy has met since its adoption. In spite of being supported unanimously by the Deans and in spite of having a fairly large population of eligible candidates at the university, courses continue to suffer from low enrollment. The article provides information on enrollment since 1984 as well as the university policy for the support of French language study by members of faculty.
\end{abstract}

\section{RÉSUMÉ}

En 1983, l'université du Nouveau-Brunswick a mis en place une politique linguistique permettant d'offrir, en français, des cours de diverses disciplines telles l'économie, l' histoire et les sciences politiques. Cet article passe en revue les circonstances qui ont mené à l'adoption de cette politique et analyse les difficultés, mais aussi les points positifs, qui sont apparus depuis que cette politique existe. Malgré la présence d'un grand nombre d'étudiants capables de suivre des cours en français et le soutien unanime des doyens, ces cours n'attirent toujours que peu de monde. Cet article présente des données relatives au taux d'inscription à ces cours depuis 1984 et souligne les mesures prises par l'Université pour encourager les professeurs à perfectionner leur français.

Bilingual education at the post-secondary level in Canada immediately brings to mind the well known institutions where students can choose to take courses in French or in English; the University of Ottawa with its blend of English and French

*French Second Language Teacher Education Centre, University of New Brunswick 
courses, Glendon College in Toronto, well known for its standard of excellence in bilingual studies, the younger but growing Université de Moncton, the Faculté St. Jean in Alberta, and also the various colleges and universities in Quebec and in other parts of French Canada.

In the past few years, as a result of the growing maturity of French immersion programs in Canada, bilingual education at the post-secondary level has acquired a new definition and has attracted a new clientele. French immersion programs started in Canada in 1965 when anglophone parents in St. Lambert, Quebec, a suburb of Montreal, requested that their children be educated in French during most of the day and that they learn to function in French while in school. This was a revolutionary concept and many people were skeptical about a program which purported to teach children math and science skills in a language which they did not know and would be only in the process of learning. Nonetheless, the St. Lambert program grew and caught the attention of parents and educators in other parts of the country. Soon, immersion programs were being implemented throughout Canada and results of very carefully controlled studies conducted through McGill University (Lambert and Tucker 1972, Genesee, 1978) and through the Ontario Institute for Studies in Education (Swain, 1978; Swain and Lapkin, 1981) showed that the programs were successful. Indeed the children understood and spoke French, they were reading in both French and English and they did not appear to have suffered any detrimental effects because of the experience. As the children moved on the Junior High School and then to Senior High School, French continued to be a priority and Immersion students enrolled in a number of academic subjects in French.

In New Brunswick, 1968 saw the introduction of the Official Languages Act in the Legislature, before the Canadian Parliament acted on the recommendations of the Bilingualism and Biculturalism (B. \& B.) Commission and proposed its own Official Languages Act in 1969. The anglophone population of New Brunswick suddenly realized that unless their children were bilingual, many opportunities in government and in their daily lives would pass them by. Because of the presence of a large number of francophones in the province, there had always been more importance given to the study of French than in some other provinces but the developments of 1968 brought a new urgency to the whole question of bilingualism, and the demand for more and better French second language programs was heard in all parts of the province. It was time for the Immersion concept to be adopted in New Brunswick. The first programs were introduced in 1969 and in the early seventies in the three major centres of Moncton, Saint John and Fredericton as well as in a few smaller communities.

In September 1988, 16,025 students were enrolled in some form of Immersion program in New Brunswick and since 1981, they have been graduating from High School and enrolling in university.

The University of New Brunswick (U.N.B) was first established in 1785 to meet the needs of the educated Loyalists who had found their way from the American colonies and settled along the Saint John River. Although New Brunswick always 
had a large number of francophone citizens, U.N.B. was established for the anglophone population and never attempted to meet the needs of francophones seeking a post-secondary education in French. Indeed, even the public school system did not respond to the legitimate requests of the francophone population until the second part of the twentieth century, when a system of public education was established to serve the needs of the francophone citizens. Part of this thrust included the founding of l'Université de Moncton in 1963.

In April 1981, the U.N.B. Senate heard the report of its Ad hoc Committee on French Language Policy. The Senate had instructed the Committee to formulate a university policy on French at both entrance and exit levels; to consider whether sufficient opportunities existed for students and faculty to acquire necessary or desirable French language skills; to consider whether U.N.B. should conduct some courses in French; and to consider other matters relevant to the French language policy at the University.

The University had been aware of the growth of immersion programs in the province and the Senate decision to look into these questions was initiated not only as a result of a concern for the recruitment of these students but also because of the timeliness of such a move. Much had been written by the Commissioner of Official Languages (Annual Reports 1979, 1980) about the role of universities in a bilingual Canada, and U.N.B., under the leadership of its bilingual president, was ready to play a more active role in providing bilingual opportunities for its students. U.N.B. had accepted francophone students for many years but this new response was a consideration of the needs of its first clientele, the anglophone students coming from English high schools in New Brunswick.

Among the recommendations of the Ad hoc Committee, were that U.N.B. not require proficiency in French as a condition of entry, and that all students not be required to study French while at U.N.B. It did, however, recommend that the French Department prepare itself to meet an increased demand for language courses and that the university immediately commit itself to the principle of offering a variety of courses in French.

As a result of the recommendations of the Committee, a French Language Policy was adopted which provided an incentive to immersion students to register at U.N.B. The Policy called for courses to be offered in French in a number of disciplines including Chemistry, Economics, History and Political Science. Further, the Policy stated that in order to insure that these goals would be achieved, the University would seek to obtain the resources necessary to make it possible. These changes not only suggested the identification of professors able to teach these courses in French but also called for the provision of adequate library and resource materials.

The Policy also addressed the changing needs in the Department of French. Traditionally, French departments saw their objectives as the transmission of literary knowledge. Courses typically dealt with literature in all its forms, as well as with linguistics and translations. The University of New Brunswick was no exception. The Department had, however, tried to offer courses which would meet 
the needs of incoming students, with language courses being offered long before the implementation of the Policy. Because of the new demand created by the arrival of the immersion graduates, the Policy called for French language courses to be offered at a level and of a type appropriate for graduates of French immersion programs in the public schools of New Brunswick. This particular requirement would prove to be the most difficult to meet. What type of program would be suitable for immersion graduates? There were no precedents to follow. There were only impressions and assumptions upon which to develop a program and a feeling that the immersion graduates would be similar to French first language rather than French second language learners.

The third major recommendation of the Policy offered Faculty the opportunity to study French to improve their linguistic facility with a view to offering sections of additional courses in French in subsequent years.

Finally, the Policy called for the appointment of a Policy coordinator who would oversee the implementation of the Policy. The coordinator's role included the identification of courses to be taught in French, the on-going evaluation of programs of preparation of faculty members to teach in French, the provision of adequate information to students, and the general coordination of all other aspects of the Policy which would be necessary from time to time. (Appendix A)

The French Language Policy at the University of New Brunswick was approved in 1983 and in the fall of 1984, students were encouraged to enroll in French courses geared to their needs and in a number of other courses taught in French. The first courses offered were Economics 1000, History 1300 and Sociology 1000. A total of 16 students enrolled in the three courses. (Appendix B) Because of the need for this exercise to succeed at the beginning, no minimum registration had been set. Two of the professors who taught the courses had, during the intervening years, obtained study leaves during which time they had improved their linguistic facility, as well as having spent some time making preparations to offer their courses. Obviously professors who offered to teach their courses in French had already demonstrated a certain degree of competence in the language. In the case of these two professors, one was granted a year of study at L'Université Laval, while the other took a refresher course at Trois-Rivieres. Since the first courses were offered in 1984, four professors have volunteered to teach courses in French, and Psychology has been added to the list. The University has since developed a set of guidelines for the support of French language study by members of the Faculty. (Appendix C).

In February 1987, Dr. James Downey, President of the University appointed a committee to review the Policy. Since the Policy was fairly new, the committee refrained from embarking on a lengthy evaluation exercise and concentrated on obtaining reactions from Faculty and students as to their impressions of the Policy.

In the "Report of the Committee to Review the U.N.B. French Language Policy" (Nov. 1987), the authors report that there was unanimous support for the Policy by the Deans. The Dean of Arts, more directly affected by the Policy, was confident that the university had met the challenge posed by the arrival of the 
immersion students and that the Policy in general had met with reasonable success.

In the other Faculties, support for the Policy was expressed in a number of ways. The Dean of Science in a letter sent to all incoming students included the following paragraph:

Students who live in a bilingual province and country and who will be entering an increasingly bilingual job market, should give more serious consideration to the study of the second official language while they are at the University. The University of New Brunswick is equipped to provide French language courses for all students, regardless of the level of proficiency they have previously acquired. To make sure that you are placed in a suitable course or section, the Department of French conducts a "placement test" during Registration Week. Furthermore, each Department of the Faculty of Science has resource people who are available to assist students on an informal basis "en français".

The Faculty of Engineering encourages student and faculty exchanges with Quebec, France and Switzerland. Furthermore, the Engineering Faculty attracts many immersion students and preliminary plans are under way to offer a section of Basic Engineering in French. The Physical Education Faculty offered a dance course in French which attracted only a few students, but students admitted to the faculty are encouraged to choose electives in French during their undergraduate degree.

In Education, of course, students have many opportunities to study in French, with all courses available to prospective teachers of French second language and Immersion being offered in French.

In Law, the Policy is very much alive with the Faculty offering a number of courses in French. With the assistance of a grant from the Secretary of State, courses in Advanced Civil Procedure, in Air Law, in Constitutional Law and later in Bilingualism and the Law have been offered in French since 1986. These courses attracted a small number of students anxious to meet the challenge of practising law in a bilingual province. Discussions are on-going with the French Department so that language courses geared to the needs of the Law Faculty can be developed.

In the French Department, language courses have been developed to meet the needs of immersion students, of francophones and of students entering university with or without grade 12 French. These courses have met with limited success and the faculty continues to search for the correct formula for its varied clientele.

Since September 1984, 115 first year students have chosen to enroll in courses taught in French outside the Department of French. In the first year of the implementation of the Policy, a majority of those students were francophones. Increasingly, anglophone students are selecting these courses.

Since 1984-85, two of the four instructors have requested that their students complete questionnaires at the end of the course. Students as a whole have appreciated having the opportunity to take courses in French and felt that they had learned the subject matter as well as having an opportunity to improve their competence in French. A number of students indicated that it had been an 
enriching experience. There was some dissatisfaction with the textbooks used and some students indicated that the texts were "too difficult to read".

In general, students enrolled in a Bachelor of Arts selected these courses, with some Business Administration students selecting Economics 1000 and some Education students selecting Psychology 1000 in French. No students from the Faculties of Nursing or Forestry and only one Engineering student opted to take any of these courses in French.

The students, in general, commented favorably about the ability of their professors to speak French and were appreciative of their efforts to offer these courses in French.

In looking ahead to 1989-90, five professors have indicated their willingness to offer one of their courses in French. A committee has been appointed to work with the co-ordinator in promoting the Policy on the campus, in other universities across Canada and in high schools throughout New Brunswick; and the Department of French continues to adjust course offerings to the needs of in-coming students.

In developing courses to meet the needs of students in the coming decade, innovative ideas for the provision of bilingual opportunities will have to be found. Cooperation between Departments in the granting of joint credits for courses will be explored. Called "sheltered courses" in Ontario, and first stared at the University of Ottawa, these courses require two instructors, one who teaches the subject matter and the other, a language instructor who facilitates comprehension of the language of instruction. Students who successfully complete the course and meet certain predetermined criteria receive two credits, one for the subject-matter taught, for instance psychology, and one in French. While the developments of the eighties demonstrated the University's willingness to meet the needs of immersion graduates who might wish to enroll in courses taught in French at U.N.B., the challenge for the University in the next decade will be to prepare graduates for life in a bilingual country.

The goals of the university as detailed over two hundred years ago by its loyalist founders have been met and surpassed. The university has grown to be a leading Canadian institution with well established Faculties in Arts, Science, Business Administration, Physical Education, Nursing, Forestry, Engineering and Law. In "Bilingual Education: A Challenge for Canadian Universities in the '90s", Leblanc (1986) summarizes the offerings in French in universities across Canada and describes U.N.B. as "a leader among Eastern Canadian post-secondary institutions in offering courses in French intended primarily for students graduating from high school immersion programs." In Canada's only officially bilingual province, it's oldest and largest university could have done no less. In the next few years the administrators of the Policy will need to move to the next step in the process, and that is to evaluation. Are immersion students enrolling in French courses improving in their ability in French? Are they more fluent than when they arrived? Are students enrolling in psychology taught in French as knowledgeable 
about psychology as their friends who enrolled in the courses which were taught in English? Further, are these students more fluent in French because of their experience in psychology in French?

During the review process, professors involved in teaching subjects in French were asked why tenured professors would expend the energy and dedication required to teach courses in another language. The answers varied but the message was the same. They did it out of a sense of duty, out of a desire to do something for their country or simply because it was the correct thing to do at that particular time. There is, then, general support for the Policy at the University, due, perhaps to the wisdom of those who first put the process into motion in 1981 .

As the university enters its third century, it is responding to the expressed needs of its students and there is ample room to grow. A system has been put into place which will allow the university to respond to the bilingual needs of its students in the coming years, as is appropriate at this stage of New Brunswick's history.

\section{NOTES}

1 Edwards, V.; Picot, J. and Rehorick, D. The Report of the Committee to Review the U.N.B. French Language Policy, U.N.B., Fredericton, N.B., 1987, p. 15-16.

\section{REFERENCES}

Department of Education. (1987-1988). Immersion statistics. Fredericton, N.B.: Department of Education.

Edwards, V., J. Picot, \& D. Rehorick. (1987). The report of the committee to review the U. N, B. French language policy. Fredericton, N.B.: University of New Brunswick.

Genesee, F. (1978). A longitudinal evaluation of an early immersion school program. Canadian Journal of Education, 3, 31-50.

Lambert, W. E., \& G. R. Tucker. (1972). Bilingual education of children: the St Lambert experiment. Rowley, MA: Newbury House.

LeBlanc, A. (1986). Bilingual education: a challenge for Canadian universities in the ' $90 \mathrm{~s}$. Winnipeg: The University of Manitoba.

Swain, M. (1978). Bilingual education for the English-speaking Canadian. In J. E. Alatis (Ed.), International dimensions of bilingual education. Georgetown University Round Table (pp. 141-154). Washington, DC: Georgetown University Press

Swain, M., \& S. Lapkin. (1981). Bilingual education in Ontario: a decade of research. Toronto: Ontario Ministry of Education.

University of New Brunswick. (1981). French language policy. Unpublished manuscript, University of New Brunswick.

University of New Brunswick. (1981). Senate ad hoc committee on French language policy. Unpublished manuscript, University of New Brunswick. 


\section{APPENDIX A}

\section{The U.N.B. French Language Policy}

I The University of New Brunswick intends to meet the needs of undergraduate students with respect to French in the following ways:

1 By providing where feasible French language courses at a level and of a type appropriate for graduates of French immersion programmes in the public schools of New Brunswick.

2 By providing where feasible French language instruction in a limited number of other subjects, particularly courses available to students in a number of faculties as electives.

3 By providing students in all faculties who are not bilingual with more information, encouragement and opportunity for the study of French.

II In order to achieve these goals the University shall seek to:

1 Ensure that the Department of French has adequate resources, in terms of numbers and training, to meet increased demands.

2 Designate sections of the following courses to be taught in French beginning in September 1984, subject to student demand and successful preparation by the instructors:

Chemistry 1000, Economics 1000, History 1300, Political Science 2020.

3 Provide opportunities for faculty with demonstrated competence in French to improve their linguistic facility with a view to offering sections of additional courses in subsequent years.

4 Inform all incoming students, by means of a letter from Deans of Faculty, of the importance of studying French and of the opportunities for doing so within the context of each degree programme.

5 Authorize the appointment of a French Language Policy Co-ordinator, whose duties will include (but not be limited to):

a the identification of possible additions to the list of courses which can be offered in French, especially upper year and professional courses (capability, suitability, demand);

b on-going evaluation of the programmes of preparation of faculty members to teach in French;

c liaison with French immersion students, in order to anticipate the demand for courses taught in French;

d co-ordination of the counselling and timetable arrangements implied in I-3 and II-4;

e liaison with instructors and librarians to attempt to ensure the adequacy of library resources to support the French language teaching programme;

f appropriate public relations. 


\section{APPENDIX B}

\section{ENROLLMENT OF STUDENTS BY FACULTY}

$$
\text { BA BBA BSC BSE BSS ED BPE STU TOTAL }
$$

\section{ECON 1000 (Argaez)}

$\begin{array}{llllllllll}1984-85 & 2 & - & - & - & - & - & - & - & 2 \\ 1985-86 & 2 & 2 & 1 & - & - & - & - & - & 5 \\ 1986-87 & - & - & - & - & - & - & - & - & - \\ 1987-88 & 4 & 4 & - & - & - & - & - & - & 8 \\ 1988-89 & 1 & - & - & - & - & - & - & - & 1\end{array}$

HIST 1300 (Vigod)

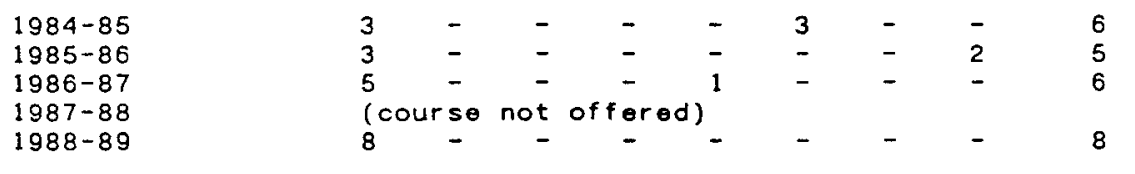

\section{PSYC 1000 (Richards)}

$\begin{array}{rrrrrrrrrr}1984-85 & - & - & - & - & - & - & - & - & - \\ 1985-86 & 1 & - & - & - & - & - & - & - & 1 \\ 1986-87 & 11 & - & - & - & - & 1 & 1 & 1 & 14 \\ 1987-88 & 11 & 1 & - & 1 & - & 5 & - & - & 18 \\ 1988-89 & - & - & - & - & - & - & - & - & -\end{array}$

\section{SOCI 1000 (Rehorick)}

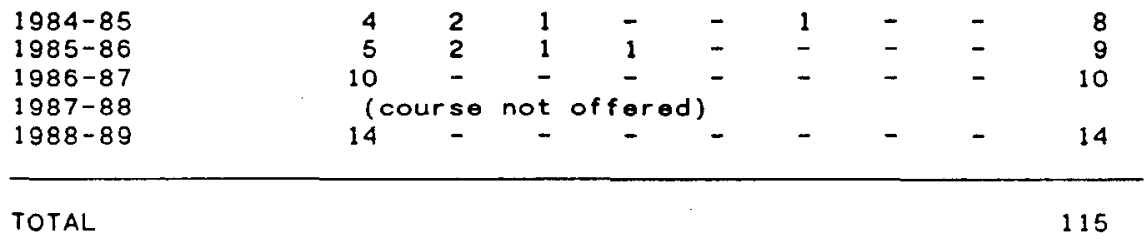




\section{APPENDIX C}

\section{Criteria for University Support of French Language Study by Members of Faculty}

The University has adopted a "French Language Policy" approved by the Senate on July 11, 1983 and subsequently by the Board of Governors on January 28, 1983. In order to achieve the goals of the policy the University undertook, among other items, to, "provide opportunities for faculty with demonstrated competence in French to improve their linguistic facility with a view to offering sections of additional courses in subsequent years' (II 3)."

The granting of leave for this purpose is to be considered Special Leave under our Collective Agreement and is to be granted at the discretion of the University. The following criteria are proposed for assessing applications for leave under the French Language Policy to ensure that such leaves the University may choose to grant, meet the objectives of the policy:

1 A course must be identified in the faculty member's Department or Faculty which it is practicable and desirable to teach in French periodically. Such courses will be identified by the Coordinator of French Language Policy, the Chairman and the Dean.

2 The faculty member must be assessed on his/her competence in French; whether he/she has the capacity to become sufficiently competent in French to teach the course identified; and if so, a reasonable estimate provided of the amount of study required to achieve such competence. The assessor(s) will be appointed by the Vice-President (Academic) and will provide the candidate and the Vice-President a written report with recommendations for future study.

3 The program of study must be appropriate to the need identified in (2). It could range in length from a summer brushing up to (at most) a full academic year. It must involve full-time study for the period identified; or, if taken in conjunction with another leave, a declaration must be provided of the proportion of the leave to be devoted to French Language study. The University must approve the particular program of study and its location.

4 The faculty member must be prepared to offer the designated course in French within one year of his/her return from the leave, provided there is sufficient demand.

5 Normally, financial support shall consist of:

a For a summer; reasonable travel, living and tuition (if it is considered necessary to leave Fredericton).

b For one term; $100 \%$ salary.

c For one year; $85 \%$ salary. 